\title{
ESTABLISHING FREQUENCY SPEED OF KICK TEST CLASSIFICATORY TABLES IN MALE AND FEMALE TAEKWONDO ATHLETES
}

\author{
Jonatas Ferreira da Silva Santos ${ }^{1,2}$, Tomás Herrera-Valenzuela ${ }^{3,4}$, and Emerson Franchini ${ }^{2}$ \\ ${ }^{1}$ Physical Training and Sport Performance Research Group, Physical Education Department, \\ Health and Biological Science Faculty, Federal University of the Jequitinhonha \\ and Mucuri Valleys, Diamantina - Minas Gerais, Brazil \\ ${ }^{2}$ Martial Arts and Combat Sports Research Group, Sport Department, \\ School of Physical Education and Sport, University of São Paulo, Brazil \\ ${ }^{3}$ Laboratory of Science of Physical Activity, Sports and Health, Faculty of Medical Sciences, \\ Universidad de Santiago de Chile, USACH, Santiago de Chile, Chile \\ ${ }^{4}$ School of Sport Sciences, Faculty of Health, Universidad Santo Tomás, UST, Chile
}

Original scientific paper

DOI: $10.26582 / \mathrm{k} .51 .2 .12$

\begin{abstract}
:
Recently, the Frequency Speed of Kick Test $\left(\mathrm{FSKT}_{10 \mathrm{~s}}\right)$ and its intermittent version $(5 \mathrm{x} 10 \mathrm{~s} / 10 \mathrm{~s}$ intervals, $\mathrm{FSKT}_{\text {mult }}$ ) have been used to assess the physical fitness of taekwondo athletes, but no classificatory normative table was found for these tests. Thus, the aim of this study was to present two normative classificatory tables for both the $\mathrm{FSKT}_{10 \mathrm{~s}}$ and $\mathrm{FSKT}_{\text {mult }}$ for male and female taekwondo athletes. One hundred fifteen male taekwondo athletes (median [interquartile range] age: 20 [17;27] years; body height: 175 [170;182] cm; body mass: 67 [60;78] kg; experience time: 6 [3;10] years) and seventy female taekwondo athletes (median [interquartile range] age: 19 [(17;24] years; body height: 162 [157;169] cm; body mass: 57 [50;64] kg; experience time: 5 [3;9] years) volunteered to participate in the study. Their skills ranged between $4^{\text {th }} g u b$ and $2^{\text {nd }} d a n$. All the participants were evaluated during their competitive period and were familiarized with this test. The classificatory tables are presented in five scales, as follows: excellent ( $\geq 95^{\text {th }}$ percentile); good ( $\geq 75^{\text {th }}$ percentile up to $94^{\text {th }}$ percentile); regular $\left(\geq 25^{\text {th }}\right.$ percentile up to $74^{\text {th }}$ percentile); poor $\left(\geq 6^{\text {th }}\right.$ percentile up to $24^{\text {th }}$ percentile); and very poor $\left(\leq 5^{\text {th }}\right.$ percentile). The classificatory tables for $\mathrm{FSKT}_{10 \mathrm{~s}}$ and $\mathrm{FSKT}_{\text {mult }}$ can help coaches and strength and conditioning professionals to classify performance and monitor the physical fitness of taekwondo athletes in different stages of training and during the competitive season.
\end{abstract}

Key words: specific test, combat sport, field test, physical performance

\section{Introduction}

Taekwondo is a complex striking combat sport that requires highly developed physical, physiological, technical, tactical and psychological characteristics of athletes for their successful competitive performance (Bridge, Santos, Chaabène, Pieter, \& Franchini, 2014). In the Olympic Games, male and female taekwondo athletes compete in four weight divisions (males: $-58 \mathrm{~kg},-68 \mathrm{~kg},-80 \mathrm{~kg}$ and +80 $\mathrm{kg}$; females: $-49 \mathrm{~kg},-57 \mathrm{~kg},-67 \mathrm{~kg}$ and $+67 \mathrm{~kg}$ ). Match simulation investigations reported a predominance of oxidative pathway, followed by ATP-PCr and glycolytic energy systems, while the main highintensity actions were supplied by ATP-PCr energy system (Campos, Bertuzzi, Dourado, Santos, \&
Franchini, 2012; Hausen, et al., 2017). Thus, it is considered that a high ATP-PCr energy system recruitment and the ability to perform successive high-intensity actions are key elements for successful performance in taekwondo matches (Bridge, et al., 2014). In a match, athletes perform brief periods of high-intensity (1.3 s) and the attack time and the number of attacks are higher in $-58 \mathrm{~kg}$ weight category compared to $+80 \mathrm{~kg}$ male taekwondo athletes (Santos, Franchini, \& Lima-Silva, 2011), suggesting different physiological adaptations modulated by weight category.

Despite the relevance of sport-specific evaluation to monitor and to prescribe training (Hoffman, 2012; Kraemer, Comstock, Clark, \& Dunn-Lewis, 2012), non-specific tests such as one-repetition 
maximum, sit-and-reach, Wingate and running maximal graded exercise tests have been frequently used to evaluate taekwondo athletes' fitness (Bridge, et al., 2014; Pieter, 1991). These tests are performed using different body positions, muscle actions and temporal characteristics than those observed during taekwondo training and competition, thus limiting their value to the taekwondo training process. In an attempt to measure and assess the physical fitness of taekwondo athletes using specific actions, some tests have been developed (Araujo, et al., 2017; Sant'Ana, et al., 2014; Sant'Ana, Franchini, Murias, \& Diefenthaeler, 2019; Santos, \& Franchini, 2018; Santos, \& Franchini, 2016; Santos, Herrera-Valenzuela, Mota, \& Franchini, 2016; Santos, Loturco, \& Franchini, 2018; Santos, Valenzuela, \& Franchini, 2015). Among these tests, the Frequency Speed of Kick Test $\left(\mathrm{FSKT}_{10 \mathrm{~s}}\right)$ is the only that is mainly related to the ATP-PCr energy system, due to its all-out nature and short duration (10 s), and that resulted in a derived version which is intermittent $\left(5 \times 10 \mathrm{~s} / 10 \mathrm{~s}\right.$ intervals, FSKT $\left._{\text {mult }}\right)$. Moreover, both tests can be easily applied in the taekwondo training facility and do not require sophisticated equipment (Santos \& Franchini, 2018; Santos \& Franchini, 2016; Santos, et al., 2018). Additionally, the FSKT is sensitive enough to identify acute (Santos, et al., 2015) and long-term performance changes (Santos \& Franchini, 2016), and has been reported to properly discriminate international/national and state/ regional female taekwondo athletes' performance (Santos \& Franchini, 2018). However, no classificatory table for the FSKT was found. Thus, the aim of this study was to develop two classificatory tables for FSKT, one for males and another for females, as an instrument to help coaches and strength and conditioning professionals to improve taekwondo athletes' classification, as well as the process of training monitoring and prescription. As taekwondo athletes are classified in weight categories, this study also compared the performance in these two tests to verify if the classification can be used for the different Olympic weight divisions.

\section{Methods}

\section{Sample}

One hundred fifteen male taekwondo athletes (by the competitive level: regional $n=24$; state $n=44$; national $n=26$; international $n=21$; by the Olympic weight category (for two male athletes the body mass was not measured): under $58 \mathrm{~kg} \mathrm{n}=21$; under $68 \mathrm{~kg} \mathrm{n}=41$; under $80 \mathrm{~kg} \mathrm{n}=33$; over $80 \mathrm{~kg} \mathrm{n}=18$ ) volunteered to participate in the study (median [interquartile range] age: 20 [17;27] years; body height: 175 [170;182] cm; body mass: 67 [60;78] kg; experience time: $6[3 ; 10]$ years). Their taekwondo skills ranged between $4^{\text {th }} g u b$ and $2^{\text {nd }} d a n$. Seventy female taekwondo athletes (by the competitive level: recreational $n=14$; regional $n=8$; state $n=20$; national $\mathrm{n}=23$; international $\mathrm{n}=5$; by the Olympic weight category: under $49 \mathrm{~kg} \mathrm{n}=16$; under $57 \mathrm{~kg}$ $\mathrm{n}=22$; under $67 \mathrm{~kg} \mathrm{n}=19$; over $67 \mathrm{~kg} \mathrm{n}=13$ ) volunteered to participate in the study (median [interquartile range] age: 19 [17;24] years; body height: 162 [157;169] cm; body mass: 57 [50;64] kg; experience time: 5 [3;9] years). Their taekwondo skills ranged between $4^{\text {th }} g u b$ and $1^{\text {st }} d a n$. All the participants were evaluated during their competitive period and were familiarized with this test. The test was conducted by an experienced evaluator (the first author of the study). Prior to testing, the athletes were informed of the procedures, including the possible risks involved, and signed an informed consent form. They were free from any injury or neuromuscular disorder. The research was approved by the Institutional Ethics Committee.

\section{Experimental procedures}

This was a descriptive study as subjects were submitted to FSKT and FSKTmult once. All the athletes involved in this study had experience with testing procedures. The tests were executed in each athlete's training center. Before the testing session, a warm-up was conducted, composed of running (self-selected jogging for 5-min), stretching (4 exercises for 15-s, below the discomfort threshold) and low-intensity kicks and punches (4 x 10 repetitions of low-intensity actions with $\sim 90$-s intervals, totaling 5-min), totaling approximately 15 minutes.

\section{Performance assessment}

Frequency Speed of Kick Test. The FSKT is $10 \mathrm{~s}$ long, and during its execution each athlete is placed in front of the stand bag equipped with a simple trunk taekwondo protector. After a command, the athlete performs the maximal number of kicks possible, alternating the right and the left leg. The turning kick, known as Bandal Tchagui, is used during the test (Santos \& Franchini, 2018; Santos \& Franchini, 2016; Santos, et al., 2018; Santos, et al., 2015). FSKT $_{10 \text { s }}$ presents a very high intraclass correlation coefficient between test-retest $(\mathrm{ICC}=.95)$. The test and retest coefficient of variation was $2.9 \%$.

Frequency Speed of Kick Test Mult. The same procedures adopted in the $\mathrm{FSKT}_{10 \mathrm{~s}}$ are used during

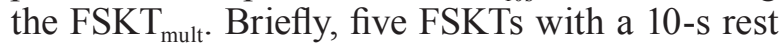
interval between repetitions are executed. Performance is determined by the total number of kicks in each set, the total number of kicks in five sets, and the kick fatigue index (Santos \& Franchini, 2018; Santos \& Franchini, 2016; Santos, et al., 2016; Santos, et al., 2018). FSKT mult presented a mean intraclass correlation coefficient $($ ICC) $=.85$ between test and retest. The mean test and retest coefficient of variation was $3.9 \%$.

Kick Decrement Index. Kick decrement indicates performance decrease during the test. To 
calculate the kick decrement the number of kicks applied during the multiple FSKT is considered. The equation takes into account the results of all FSKT sets (Equation) (Girard, Mendez-Villanueva, \& Bishop, 2011).

KICK DECREMENT INDEX $(\%)=$

$\left[1-\frac{(\text { FSKT1+FSKT2+FSKT3+FSKT4+FSKT5) }}{\text { Best FSKT SET X Number of Sets }}\right] \times 100$

(Equation)

Video analysis. Kinovea software (Kinovea ${ }^{\circledR}$, Version 0.8.15) was used to count the kicks applied during the FSKT. If the athlete started a kick before completing $10 \mathrm{~s}$, but reached the target only after $10 \mathrm{~s}$ period has elapsed, the kick was not considered valid.

\section{Statistical analysis}

Seven variables were considered $\left(\mathrm{FSKT}_{10 \mathrm{~s}}\right.$, $\mathrm{FSKT}_{\text {mult }}-\mathrm{FSKT}_{1}, \mathrm{FSKT}_{2}, \mathrm{FSKT}_{3}, \mathrm{FSKT}_{4}, \mathrm{FSKT}_{5}$ and $\left.\mathrm{FSKT}_{\text {total }}\right)$. A five-point scale using percentile values was adopted to establish the following categories for each variable: excellent $\left(\geq 95^{\text {th }}\right.$ percentile); good ( $\geq 75^{\text {th }}$ percentile up to $94^{\text {th }}$ percentile); regular $\left(\geq 25^{\text {th }}\right.$ percentile up to $74^{\text {th }}$ percentile); poor ( $\geq 6^{\text {th }}$ percentile up to $24^{\text {th }}$ percentile); and very poor $\left(\leq 5^{\text {th }}\right.$ percentile) after the analysis of data distribution to classify variables. The Kolmogorov-Smirnov test $\left(D_{\mathrm{K}-\mathrm{S}}\right)$ was used to assess data normality, which was not confirmed. The level of significance was set at $5 \%$. To compare weight categories the Kruskal Wallis test and the Mann-Whitney test with Bonferroni correction were used. The level of significance to post-hoc was at $.0083 \%$. The effect size (ESr) was calculated using the following formula: $r=Z / \sqrt{N}$ (Rosenthal, 1991) and classified using the following scale (Hopkins, 2006): $\leq 0.2$ (trivial); $>0.2-0.6$ (small); >0.6 - 1.2 (moderate); >1.2 - 2.0 (large); $>2.0$ (very large).

\section{Results}

The main results of FSKT $10 \mathrm{~s}$ and $\mathrm{FSKT}_{\text {mult }}$ are presented in Tables 1 to 4 for males and females respectively.

\section{Male taekwondo athletes}

Male classificatory table for the Frequency Speed of Kick Test is presented in Table 1 and performance in FSKT by weight categories is presented in Table 2. No difference was observed considering weight categories for $\mathrm{FSKT}_{10 \mathrm{~s}}(\mathrm{H}[3]=3.74, \mathrm{p}>.05), \mathrm{FSKT}_{1}$ $(\mathrm{H}[3]=5.10, \mathrm{p}>.05), \mathrm{FSKT}_{2}(\mathrm{H}[3]=4.73, \mathrm{p}>.05)$, FSKT $_{5}(\mathrm{H}[3]=5.13, \mathrm{p}>.05), \operatorname{FSKT}_{\text {total }}(\mathrm{H}[3]=6.89$, $\mathrm{p}>.05$ ). Despite a significant difference in $\mathrm{FSKT}_{3}$ $(\mathrm{H}[3]=9.49, \mathrm{p}=.02)$ established by Kruskal-Wallis, no differences were identified in the post-hoc $(-58 \mathrm{~kg}$ vs $-68 \mathrm{~kg}$ : $\mathrm{U}=422.00, \mathrm{p}=.90 ;-58 \mathrm{~kg}$ vs $-80 \mathrm{~kg}$ : $\mathrm{U}=$

Table 1. Male classificatory table for the Frequency Speed of Kick Test ( $n=115)$

\begin{tabular}{|c|c|c|c|c|c|c|c|c|}
\hline \multirow[b]{2}{*}{ Classification } & \multirow[b]{2}{*}{$\begin{array}{l}\mathrm{FSKT}_{10 \mathrm{~s}} \\
\text { (kicks) }\end{array}$} & \multicolumn{7}{|c|}{ FSKTmult } \\
\hline & & $\begin{array}{l}\mathrm{FSKT}_{1} \\
\text { (kicks) }\end{array}$ & $\begin{array}{l}\mathrm{FSKT}_{2} \\
\text { (kicks) }\end{array}$ & $\begin{array}{l}\mathrm{FSKT}_{3} \\
\text { (kicks) }\end{array}$ & $\begin{array}{l}\mathrm{FSKT}_{4} \\
\text { (kicks) }\end{array}$ & $\begin{array}{l}\mathrm{FSKT}_{5} \\
\text { (kicks) }\end{array}$ & $\begin{array}{l}\mathrm{FSKT}_{\text {total }} \\
\text { (kicks) }\end{array}$ & KDI (\%) \\
\hline Excellent & $\geq 24$ & $\geq 24$ & $\geq 23$ & $\geq 22$ & $\geq 20$ & $\geq 20$ & $\geq 108$ & $\leq 3.3$ \\
\hline Good & $22-23$ & $22-23$ & $21-22$ & $20-21$ & 19 & 19 & $97-107$ & $3.4-5.9$ \\
\hline Regular & $18-21$ & $19-21$ & $18-20$ & $17-19$ & $16-18$ & $16-18$ & $85-96$ & $6.0-11.4$ \\
\hline Poor & 17 & 18 & 17 & 16 & 15 & 15 & $80-84$ & $11.5-19.9$ \\
\hline Very poor & $\leq 16$ & $\leq 17$ & $\leq 16$ & $\leq 15$ & $\leq 14$ & $\leq 14$ & $\leq 79$ & $\geq 20.0$ \\
\hline
\end{tabular}

Note. FSKT: Frequency Speed of Kick Test; KDI: Kick Decrement Index.

Table 2. Male performance in the Frequency Speed of Kick Test divided by weight category ( $n=113)$; data are presented as median and (interquartile range)

\begin{tabular}{|c|c|c|c|c|c|c|c|c|}
\hline \multirow[b]{2}{*}{ Weight Category } & \multirow[b]{2}{*}{$\begin{array}{l}\mathrm{FSKT}_{10 \mathrm{~s}} \\
\text { (kicks) }\end{array}$} & \multicolumn{7}{|c|}{ FSKTmult } \\
\hline & & $\begin{array}{l}\mathrm{FSKT}_{1} \\
\text { (kicks) }\end{array}$ & $\begin{array}{l}\mathrm{FSKT}_{2} \\
\text { (kicks) }\end{array}$ & $\begin{array}{l}\mathrm{FSKT}_{3} \\
\text { (kicks) }\end{array}$ & $\begin{array}{l}\mathrm{FSKT}_{4} \\
\text { (kicks) }\end{array}$ & $\begin{array}{l}\mathrm{FSKT}_{5} \\
\text { (kicks) }\end{array}$ & $\begin{array}{c}\mathrm{FSKT}_{\text {total }} \\
\text { (kicks) }\end{array}$ & KDI (\%) \\
\hline$-58 \mathrm{~kg}$ & $\begin{array}{c}20 \\
(19 ; 22)\end{array}$ & $\begin{array}{c}21 \\
(19 ; 23)\end{array}$ & $\begin{array}{c}19 \\
(18 ; 21)\end{array}$ & $\begin{array}{c}19 \\
(18 ; 20)\end{array}$ & $\begin{array}{c}18 \\
(17 ; 19)\end{array}$ & $\begin{array}{c}17 \\
(16 ; 19)\end{array}$ & $\begin{array}{c}93 \\
(88 ; 101)\end{array}$ & $\begin{array}{c}9.5 \\
(8.1 ; 12.2)\end{array}$ \\
\hline$-68 \mathrm{~kg}$ & $\begin{array}{c}20 \\
(18 ; 22)\end{array}$ & $\begin{array}{c}19 \\
(19 ; 22)\end{array}$ & $\begin{array}{c}19 \\
(18 ; 21)\end{array}$ & $\begin{array}{c}18 \\
(18 ; 20)\end{array}$ & $\begin{array}{c}18 \\
(17 ; 19)\end{array}$ & $\begin{array}{c}17 \\
(16 ; 19)\end{array}$ & $\begin{array}{c}91 \\
(87 ; 100)\end{array}$ & $\begin{array}{c}7.1 \\
(4.5 ; 10.3)\end{array}$ \\
\hline$-80 \mathrm{~kg}$ & $\begin{array}{c}19 \\
(18 ; 21)\end{array}$ & $\begin{array}{c}20 \\
(18 ; 21)\end{array}$ & $\begin{array}{c}19 \\
(18 ; 20)\end{array}$ & $\begin{array}{c}18 \\
(17 ; 19)\end{array}$ & $\begin{array}{c}17 \\
(16 ; 18)\end{array}$ & $\begin{array}{c}16 \\
(16 ; 18)\end{array}$ & $\begin{array}{c}89 \\
(85 ; 95)\end{array}$ & $\begin{array}{c}8.6 \\
(6.0 ; 11.7)\end{array}$ \\
\hline$+80 \mathrm{~kg}$ & $\begin{array}{c}19 \\
(19 ; 21)\end{array}$ & $\begin{array}{c}19 \\
(18 ; 21)\end{array}$ & $\begin{array}{c}18 \\
(17 ; 20)\end{array}$ & $\begin{array}{c}18 \\
(17 ; 19)\end{array}$ & $\begin{array}{c}17 \\
(16 ; 18)\end{array}$ & $\begin{array}{c}16 \\
(16 ; 18)\end{array}$ & $\begin{array}{c}88 \\
(83 ; 95)\end{array}$ & $\begin{array}{c}7.1 \\
(5.5 ; 12.1)\end{array}$ \\
\hline
\end{tabular}

Note. FSKT: Frequency Speed of Kick Test; KDI: Kick Decrement Index. 
Table 3. Female classificatory table for the Frequency Speed of Kick Test ( $n=70)$

\begin{tabular}{|c|c|c|c|c|c|c|c|c|}
\hline \multirow[b]{2}{*}{ Classification } & \multirow[b]{2}{*}{$\begin{array}{l}\mathrm{FSKT}_{10 \mathrm{~s}} \\
\text { (kicks) }\end{array}$} & \multicolumn{6}{|c|}{ FSKTmult } & \multirow[b]{2}{*}{ KDI (\%) } \\
\hline & & $\begin{array}{l}\mathrm{FSKT}_{1} \\
\text { (kicks) }\end{array}$ & $\begin{array}{l}\mathrm{FSKT}_{2} \\
\text { (kicks) }\end{array}$ & $\begin{array}{l}\mathrm{FSKT}_{3} \\
\text { (kicks) }\end{array}$ & $\begin{array}{l}\mathrm{FSKT}_{4} \\
\text { (kicks) }\end{array}$ & $\begin{array}{l}\mathrm{FSKT}_{5} \\
\text { (kicks) }\end{array}$ & $\begin{array}{l}\mathrm{FSKT}_{\text {total }} \\
\text { (kicks) }\end{array}$ & \\
\hline Excellent & $\geq 22$ & $\geq 22$ & $\geq 21$ & $\geq 20$ & $\geq 20$ & $\geq 19$ & $\geq 97$ & $\leq 1.2$ \\
\hline Good & 21 & 21 & 20 & 19 & 19 & 18 & $92-96$ & $1.3-3.4$ \\
\hline Regular & $17-20$ & $18-20$ & $17-19$ & $16-18$ & $16-18$ & $15-17$ & $82-91$ & $3.5-10.5$ \\
\hline Poor & 16 & 17 & 16 & 15 & 15 & 14 & $73-81$ & $10.6-14.4$ \\
\hline Very poor & $\leq 15$ & $\leq 16$ & $\leq 15$ & $\leq 14$ & $\leq 14$ & $\leq 13$ & $\leq 72$ & $\geq 14.5$ \\
\hline
\end{tabular}

Note. FSKT: Frequency Speed of Kick Test; KDI: Kick Decrement Index.

Table 4. Female performance in the Frequency Speed of Kick Test divided by weight category (n=70); data are presented as median and (interquartile range)

\begin{tabular}{|c|c|c|c|c|c|c|c|c|}
\hline \multirow[b]{2}{*}{ Weight Category } & \multirow[b]{2}{*}{$\begin{array}{c}\mathrm{FSKT}_{10 \mathrm{~s}} \\
\text { (kicks) }\end{array}$} & \multicolumn{7}{|c|}{ FSKTmult } \\
\hline & & $\begin{array}{l}\mathrm{FSKT}_{1} \\
\text { (kicks) }\end{array}$ & $\begin{array}{l}\mathrm{FSKT}_{2} \\
\text { (kicks) }\end{array}$ & $\begin{array}{l}\mathrm{FSKT}_{3} \\
\text { (kicks) }\end{array}$ & $\begin{array}{l}\mathrm{FSKT}_{4} \\
\text { (kicks) }\end{array}$ & $\begin{array}{l}\mathrm{FSKT}_{5} \\
\text { (kicks) }\end{array}$ & $\begin{array}{c}\mathrm{FSKT}_{\text {total }} \\
\text { (kicks) }\end{array}$ & KDI (\%) \\
\hline$-49 \mathrm{~kg}$ & $\begin{array}{c}18 \\
(17 ; 20)\end{array}$ & $\begin{array}{c}18 \\
(17 ; 20)\end{array}$ & $\begin{array}{c}18 \\
(17 ; 19)\end{array}$ & $\begin{array}{c}17 \\
(16 ; 18)\end{array}$ & $\begin{array}{c}17 \\
(15 ; 18)\end{array}$ & $\begin{array}{c}16 \\
(15 ; 17)\end{array}$ & $\begin{array}{c}85 \\
(82 ; 90)\end{array}$ & $\begin{array}{c}6.4 \\
(5.1 ; 8.3)\end{array}$ \\
\hline$-57 \mathrm{~kg}$ & $\begin{array}{c}19 \\
(18 ; 20)\end{array}$ & $\begin{array}{c}19 \\
(18 ; 20)\end{array}$ & $\begin{array}{c}18 \\
(18 ; 19)\end{array}$ & $\begin{array}{c}18 \\
(17 ; 18)\end{array}$ & $\begin{array}{c}17 \\
(16 ; 18)\end{array}$ & $\begin{array}{c}17 \\
(16 ; 17)\end{array}$ & $\begin{array}{c}88 \\
(82 ; 90)\end{array}$ & $\begin{array}{c}8.3 \\
(3.2 ; 10.5)\end{array}$ \\
\hline$-67 \mathrm{~kg}$ & $\begin{array}{c}19 \\
(17 ; 20)\end{array}$ & $\begin{array}{c}19 \\
(17 ; 20)\end{array}$ & $\begin{array}{c}18 \\
(17 ; 20)\end{array}$ & $\begin{array}{c}17 \\
(16 ; 18)\end{array}$ & $\begin{array}{c}17 \\
(16 ; 18)\end{array}$ & $\begin{array}{c}16 \\
(16 ; 17)\end{array}$ & $\begin{array}{c}87 \\
(82 ; 93)\end{array}$ & $\begin{array}{c}7.8 \\
(3.5 ; 9.5)\end{array}$ \\
\hline$+67 \mathrm{~kg}$ & $\begin{array}{c}18 \\
(17 ; 20)\end{array}$ & $\begin{array}{c}19 \\
(18 ; 20)\end{array}$ & $\begin{array}{c}18 \\
(17 ; 19)\end{array}$ & $\begin{array}{c}17 \\
(16 ; 18)\end{array}$ & $\begin{array}{c}16 \\
(15 ; 17)\end{array}$ & $\begin{array}{c}15 \\
(15 ; 16)\end{array}$ & $\begin{array}{c}85 \\
(80 ; 89)\end{array}$ & $\begin{array}{c}10.0 \\
(3.4 ; 11.1)\end{array}$ \\
\hline
\end{tabular}

Note. FSKT: Frequency Speed of Kick Test; KDI: Kick Decrement Index.

$227.50, \mathrm{p}=.31 ;-58 \mathrm{~kg}$ vs $+80 \mathrm{~kg}: \mathrm{U}=130.50, \mathrm{p}=.10$; $-68 \mathrm{~kg}$ vs $-80 \mathrm{~kg}: \mathrm{U}=445.00, \mathrm{p}=.01 ;-68 \mathrm{~kg}$ vs +80 kg: $\mathrm{U}=253.00, \mathrm{p}=.52$ and $-80 \mathrm{~kg}$ vs $+80 \mathrm{~kg}: \mathrm{U}=$ 295.50, $\mathrm{p}=.98$ ). Only performance during $\mathrm{FSKT}_{4}$ differed between weight categories. The athletes from the $-68 \mathrm{~kg}$ performed better $(\mathrm{U}=403.50, \mathrm{p}$ $=.003, \mathrm{ESr}=-.35$ [small]) than the athletes from $-80 \mathrm{~kg}$. KDI was smaller (U: $243.50, \mathrm{p}=.005, \mathrm{ESr}=$ -.35 [small]) for the $-58 \mathrm{~kg}$ compared to the $-68 \mathrm{~kg}$ weight category.

\section{Female taekwondo athletes}

Female classificatory table for the Frequency Speed of Kick Test is presented in Table 3 and performance in FSKT by weight category in Table 4. No difference was observed considering weight categories for $\mathrm{FSKT}_{10 \mathrm{~s}}(\mathrm{H}[3]=.65, \mathrm{p}>.05), \mathrm{FSKT}_{1}$ $(\mathrm{H}[3]=2.10, \mathrm{p}>.05), \operatorname{FSKT}_{2}(\mathrm{H}[3]=1.29, \mathrm{p}>.05)$, $\mathrm{FSKT}_{3}(\mathrm{H}[3]=1.83, \mathrm{p}>.05), \mathrm{FSKT}_{4}(\mathrm{H}[3]=2.60$, $\mathrm{p}>.05), \operatorname{FSKT}_{5}(\mathrm{H}[3]=7.16, \mathrm{p}>.05), \mathrm{FSKT}_{\text {total }}(\mathrm{H}[3]=$ $2.49, \mathrm{p}>.05)$, and $\mathrm{KDI}(\mathrm{H}[3]=1.66, \mathrm{p}>.05)$.

\section{Discussion and conclusion}

The main purpose of the present study was to develop two classificatory tables for the Frequency Speed of Kick Test, one for males and another for females. Two tests were used, FSKT $_{10 \mathrm{~s}}$ and $\mathrm{FSKT}_{\text {mult }}$, and kicks by set and total kicks were used to create the classificatory tables. No differences were generated in FSKT variables regarding weight categories for the female group. For males, as only $\mathrm{FSKT}_{4}$ and KDI differed between weight categories, caution is needed when analyzing athletes from different weight categories for these two variables. However, for all the other variables, male athletes from different weight categories can be properly classified.

This is the first study to present taekwondospecific classificatory tables for both male and female athletes. A previous study conducted with female taekwondo athletes described the difference in FSKT performance between the groups divided by competitive levels (national/international vs regional/state) (Santos \& Franchini, 2018). Additionally, until the present moment no description in performance of FSKT was reported among male taekwondo athletes of different competitive levels.

The classificatory tables presented here can help coaches to monitor their athletes' training evolution, classify their performance for selection purposes and monitor short-term variation in performance in intensified or tapering training phases. Previous studies reported FSKT performance improvement after acute complex exercise (Santos, et al., 2015) and after eleven weeks of taekwondo-specific plus strength and conditioning training (Santos \& Franchini, 2016). Another possible application is the 
rehabilitation process, i.e., coaches can compare athletes' FSKT regular results with performance after the rehabilitation to establish the progress to more complex taekwondo-specific exercises according to the athletes' physical fitness.

Need analysis is a key element in training organization, and it involves metabolic, biomechanical and injury profiles (Hoffman, 2012; Kraemer, et al., 2012; Rhea \& Peterson, 2012). The FSKT presents both metabolic (i.e., it is intense and the intermittent protocol can be used) and biomechanical (i.e., the technique used is the main technique applied during high-level taekwondo competitions) specificity. Additionally, these two FSKT protocols can be easily applied by the athletes' coaches, they do not require the use of expensive material, can be applied in the athlete's training site, and as it involves taekwondo-specific actions, athletes feel more motivated to execute them compared to other non-specific tests. Moreover, the FSKT normative table can be used to classify performance of male and female competitors from different weight categories as only two variables differed between weight categories and the magnitude of these differences was quite small. Future studies should be conducted to classify the FSKT performance of athletes from different age groups.

Based on the classificatory tables presented, it is possible to classify taekwondo-specific anaerobic fitness and high-intensity intermittent performance, monitor the training progress and establish goals for taekwondo athletes from different weight categories, providing coaches and strength and conditioning professionals with an important tool to objectively deal with these aspects that are considered key elements during training organization.

\section{References}

Araujo, M.P., Nóbrega, A.C.L., Espinosa, G., Hausen, M.R., Castro, R.R.T., Soares, P.P., et al. (2017). Proposal of a new specific cardiopulmonary exercise test for taekwondo athletes. Journal of Strength and Conditioning Research, 31(6), 1525-1535.

Bridge, C.A., Santos, J.F.S., Chaabène, H., Pieter, W., \& Franchini E. (2014). Physical and physiological profile of taekwondo athletes. Sports Medicine, 44(6), 713-733.

Campos, F.A.D., Bertuzzi, R., Dourado, A.C., Santos, V.G., \& Franchini, E. (2012). Energy demands in taekwondo athletes during combat simulation. European Journal of Applied Physiology, 112(4), 1221-1228.

Girard, O., Mendez-Villanueva, A., \& Bishop, D. (2011). Repeated-sprint ability - Part I: Factors contributing to fatigue. Sports Medicine, 41(8), 673-694.

Hausen, M., Soares, P.P., Araujo, M.P., Porto, F., Franchini, E., Bridge, C.A., et al. (2017). Physiological responses and external validity of a new setting for taekwondo combat simulation. Plos One, 12, e0171553.

Hoffman, J.R. (2012). Athlete testing and program evaluation. In J.R. Hoffman (Ed.), NSCA's guide to program design (pp. 23-49). Champaign, IL: Human Kinetics.

Hopkins, W.G. (2006). A new view of statistics: A scale of magnitude for effect statistics. Retrieved July 5, 2017 from: http://www.sportsci.org/resource/stats/

Kraemer, W.J., Comstock, B.A., Clark, J.E., \& Dunn-Lewis, C. (2012). Athletes needs analysis. In J.R. Hoffman (Ed.), NSCA's guide to program design (pp. 1-21). Champaign, IL: Human Kinetics.

Pieter, W. (1991). Performance characteristic of elite taekwondo athletes. Korean Journal of Sport Science, 3, 94-117.

Rhea, M., \& Peterson, M. (2012). Tests, data analysis, and conclusions. In T. Miller (Ed.), NSCA's guide to tests and assessments (pp. 1-14). Champaign, IL: Human Kinetics.

Rosenthal, R. (1991). Meta-analytic procedures for social research. Newbury Park, CA: Sage.

Sant'Ana, J., Diefenthaeler, F., Dal Pupo, J., Detanico, D., Guglielmo, L.G.A., \& Santos, S.G. (2014). Anaerobic evaluation of taekwondo athletes. International SportMed Journal, 15(4), 492-499.

Sant'Ana, J., Franchini, E., Murias, J., \& Diefenthaeler, F. (2019). Validity of a taekwondo specific test to measure $\mathrm{VO}_{2 \text { peak }}$ and the heart rate deflection point. Journal of Strength and Conditioning Research, 33(9), 2523-2529.

Santos, J.F.S., \& Franchini, E. (2018). Frequency Speed of Kick Test performance comparison between female taekwondo athletes. Journal of Strength and Conditioning Research, 32(19), 2934-2938.

Santos, J.F.S., \& Franchini, E. (2016). Is Frequency Speed of Kick Test responsive to training? A study with taekwondo athletes. Sport Sciences for Health, 12(3), 377-382.

Santos, J.F.S., Herrera-Valenzuela, T., Mota, G.R., \& Franchini, E. (2016). Influence of half-squat intensity and volume on the subsequent countermovement jump and Frequency Speed of Kick Test performance in taekwondo athletes. Kinesiology, 48(1), 95-102. 
Santos, J.F.S., Loturco, I., \& Franchini, E. (2018). Relationship between Frequency Speed of Kick Test performance, optimal load, and anthropometric variables in black-belt taekwondo athletes. Ido Movement for Culture. Journal of Martial Arts Anthropology, 18(1), 39-44.

Santos, J.F.S., Valenzuela, T.H., \& Franchini, E. (2015). Can different conditioning activities and rest intervals affect the acute performance of taekwondo turning kick? Journal of Strength and Conditioning Research, 29(6), 1640-1647.

Santos, V.G.F., Franchini, E., \& Lima-Silva, A.E. (2011). Relationship between attack and skipping in taekwondo contests. Journal of Strength and Conditioning Research, 25(6), 1743-1751.

Submitted: March 19, 2018

Accepted: September 21, 2018

Published Online First: November 15, 2019

Correspondence to:

Jonatas Ferreira da Silva Santos

Physical Education Department, Health and

Biological Science Faculty, Federal University of the

Jequitinhonha and Mucuri Valleys, Diamantina -

Minas Gerais, Brazil

Rodovia MGT 367 - Km 583, nº 5000 - Alto da

Jacuba

ZIP CODE: 39100000 - Diamantina, MG, Brazil

Orcid code: 0000-0002-3309-4731

E-mail: jonatas_contato@hotmail.com 